高く北入问与1羽を認めた。

フルマカモメ Fulmarus glacialis

层屋崎から $1 \mathrm{~km}$ の海上て暗色型のもの 2 羽妾認めた。

ハシボソミズナギドリ Puffinus tenuirostris

北緯 $37^{\circ} 40^{\prime}$ 以南で認めた。

オオミズナギドリ Calonectris leucomelas

北緯 $40^{\circ} 10^{\prime}$ 以南。た龙し，大部分は北緯 $36^{\circ} 30^{\prime}$ 以南で楒めた。

コアホウドリ Diomedea immutabilis

26 日の午前中，北緯 $35^{\circ} 45^{\prime}$ と $38^{\circ}$ の間に合計 40 羽孝数えた。また，27日に北緯 $41^{\circ}$ 地点 で 1 羽莸認农。

クロアシアホウドリ Diomedea nigripes

26 日に北緯 $36^{\circ}$ 付近で 3 羽, 27 日に $41^{\circ}$ 付近で 1 羽を楒めた。

ハシブトウミガラス Uria lomvia

27 日に冬羽 1 羽と夏羽 1 羽を認好。本種とウミガラスは近距離てないと区別がでを ないなる見逃した多のが若干あると思ら。

ウミスズメ Synthliboramphus antiquus

北緯 $40^{\circ} 20^{\prime}$ 以南心諗めた。

エトロフウミスズメ Aethia cristatella

27日に4つの群 (125羽，460羽，550羽，800羽）を観察した。これらの群がをがんに 重複し会っているかどらかはよく判らなかった。この日は風が強く風力 6 〜 7であっ

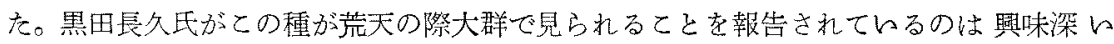
(Vogel, No, 12，1955年)。

コウミスズメ Aethia pusilla

北繰 $41^{\circ} 15^{\prime}$ 以北で認めた。

\title{
三重県におけるアマッバメ（Apus pacificus）のコロニー
}

橋 本太 郎*

\section{Summaxy}

\section{A breeding colony of the White-rumped Swift}

\section{found in Mie Prefecture}

Taro Hashimoto

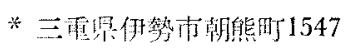


A breeding colony of Apus pacificus was found in 1967 on a coasted coastal island, Mimianajima, southern Kii Penisula, Honshu. It was in the dark crevice of the cliff about $10 \mathrm{~m}$ from the sea surface. A nest and its chicks were examided and are described briefly.

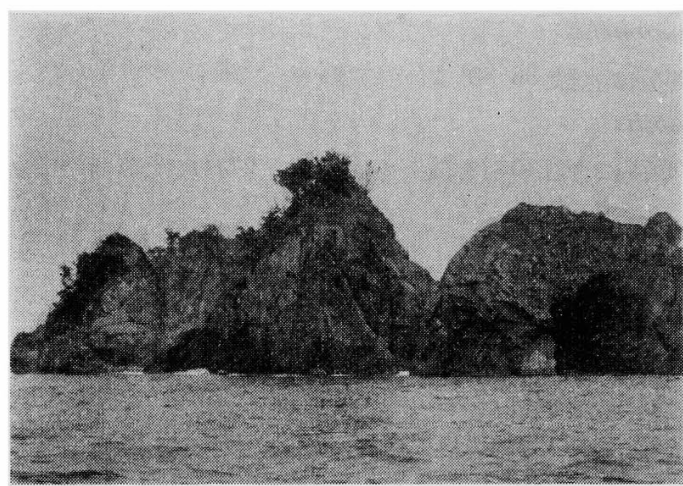

Fig. 1 The view of the eorroundings of the nest.

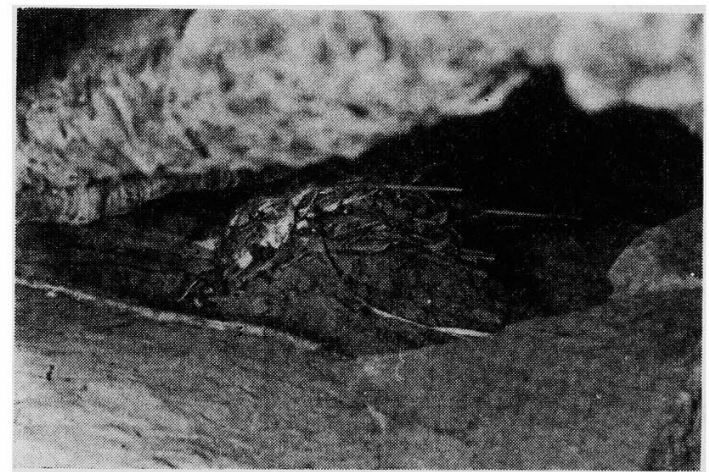

Fig. 2 Incubating in its nest. the nest is situated about $700 \mathrm{~cm}$ from front of a slit in a rock.
三重県におけるアマツバメの 観察は春秋の渡りに上空を飛翔 する群が各地で見られ，決して 珍らしいものではないが，蕃殖 の調査は懸案のまま過ごされて きた。1962年 8 月 8 日，伊勢市 内の新聞記者の一行に加わって 紀伊半島三重県側の島勝へシイ ラ釣りを試みた帰路，島勝沖の 海中にある岩山に多数のアマッ バメが群飛しているのを観察, 蕃殖の疑問をいだきながら再調 査を期して帰った。

その後毎年 6 月を期して調査 を計画したが支障が生じて行け なかった。1967年春, 倉田篤君 等が長島湾外の鈴島にマガモが 蕃殖しているらしいという報告 を得，6月 4 日雨中に舟を出し た際同行してアマツバメのよう すを観察したが，ての附近に点 在する孤島にはんづれも每数な がらアマツバメが飛翔するのが 認められた。よって蕃殖の疑い が濃厚になったので口を改め,

6 月18日，長島高校の山本祐嗣先生をわずらわせて便船を得，先生と筆者と同校生物ク ラブ生 3 名の応援と\&5名で長島湾外の耳穴島にんってみた。当日は半晴で少し風波が あったが，無理に接岸して上陸し，かねて海上から見当をつけて和々た附近の岩壁の割 目を探索したととろ，抱卵中の二栄を発見するととができ蕃殖が確認された。

写真の巣は海面から凡そ $10 \mathrm{~m}$ 程の岩壁の細い割目の奥にあり, 大人の腕がやっと入る 程度で前面から $70 \mathrm{~cm}$ 程のらすぐらん奥にわずかな土の支えをつくり，その上に巣材を 


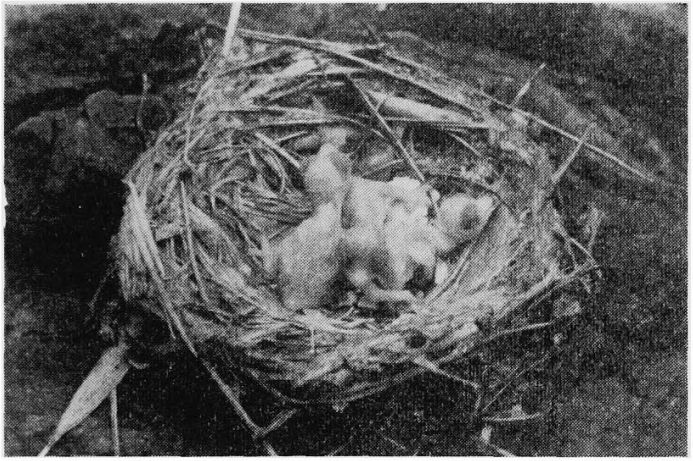

Fig. 3 The nest and nestlings in close view.

まとめて作られている。前面か らのぞんても抱卵中と思われる 親鳥は平然として巣に伏せてい て動かない。試みに木の枝で押 してみても，わずかに体をずら せるだけであった。割目と平行 にストロボをつかって撮影し た。次いで県内を調べるため, 木の校で巣を静かに入口に移動 させると，親島はとびたたずに 奥の活らにかくれてしまった。 栄を岩上に移してみると畹化後 2〜3 日の雛 3 羽と卵款の一部があった（他の巣は手をふれず）。

ひなは全裸でうす赤く，目はとじていた。觜の先に黒点があり，口角にふつらな黄色 の附属物がない。残された卵款は白色である。

巣は直径約 $10 \mathrm{~cm}$ 高さ約 $3 \mathrm{~cm}$ の皿型で巣材はイネ科の枯れた蕉葉を主としてタケの葉を 混じ，中央を除く周囲と側面はセメダインでくっつけたように透明な唾液でかためられ 泥土は殆んどつかわれていない。

以上の観察と記録写真をとり巣は元に戻して和々た。

この日耳穴島周辺には約150羽のアマツバメが群飛して和り，そのうちの 2 羽を採集し たが (農林省許可証昭 42 ，第 128 号)，胃の内容は羽蟻を飽食しているとてろから特に羽 蟻の発生に群れていたものと思われる。海上から島の一般を観察したとてろでは，同島 には他に 2 ケ所，時々親鳥が飛入するととろがあったが，洞穴や崖になっていて，ロー プをつかわないと調査できない。午後は波が荒らくなったので大島，鈴島，ダイヤ島を まわったが，大島に $2 \sim 3$ 羽，ダイヤ島に 2 羽を久ただけであった。

以上 2 回の調查の状況から，太平洋に面した断崖と洞穴の割目には多くのアマッバメ が蕃殖しているものと推定される。然し剅目の間といら条件を考えると，あ屯り大きい コロニーは想像でをない。又機会があれば再調查をしてタをい。 